\title{
Macro and micro determinants of the non-performing finance: The case of Indonesian Islamic bank
}

\author{
Anggia Zainur Rahmah*, Sheema Haseena Armina \\ Faculty of Economics and Bussiness, Universitas Airlangga, Surabaya, Indonesia \\ ${ }^{*}$ Corresponding author: anggia.zainur.rahmah-2018@pasca.unair.ac.id
}

Keywords:

Islamic bank, non-performing

finance, gross domestic product

\section{Article History}

Received: 03 December 2019

Accepted: 06 January 2020

Published: 30 January 2020

DOI:

10.20885/JEKI.vol6.iss1.art4

JEL: A10, E44, G21, Z12

\begin{abstract}
Doubtful finance showing a bad performance of a company, but this can be avoided if the banks use the right strategy to prevent such financial condition. This study aims to indicate the determinants of doubtful finance in the Indonesian Islamic banking sector from 2011 to 2018. We employed panel data regression to meet our objectives. Our results depict that banks' profitability and finance to deposit ratio have a significant positive impact on Non-Performing Finance. On the other hand, Gross Domestic Product has a significant positive effect on doubtful finance. This study provides an alluded picture of Indonesian Islamic banking sectors, particularly Non-Performing Finance (NPF). Moreover, it enables policymakers to deliberate on the macroeconomic determinants of NPFs (i.e. GDP). Furthermore, this study will enhance the Islamic bank's performance literature.
\end{abstract}

\section{Cite This:}

Rahmah, A.Z., Armina. S.H. (2020). Macro and Micro Determinants of the Non-Performing Finance: The Case of Indonesian Islamic Bank. Jurnal Ekonomi dan Keuangan Islam, 6(1), 34-41. DOI: 10.20885/jeki.vol6.iss1.art4

\section{Introduction}

The banking industry has become one of the industries that has an essential role in the economy for improving the quality of healthy banking to bring an impact on a country's economic conditions. The development of the banking industry shows two primary forms in its activities in the banking industry, namely Conventional Banks and Islamic Banks. The presence of Islamic banks is still relatively a new player in the competition of the banking industry, but the development of Islamic Banks has been improved. One indicator shows that the market share of Islamic banks is still relatively low compared to conventional banks. Based on data from (OJK, 2019) shows that the market share of Islamic banking in Indonesia is only around 5.94\%, which dominated by Islamic Banks with $64.62 \%$ market share, followed by Sharia business unit (UUS) and Sharia Rural Banks (BPRS) with 32.86\% and 2.52\% respectively. The growth of Islamic banking in Indonesia should be able to increase rapidly because according to Sudarsono (2009), Sharia banking system has more stable conditions compared to the conventional one in facing the global financial crisis. Besides, more than $80 \%$ of Indonesia's population is Muslim. This should be able to become one of the strengths of Islamic banking to improve its performance so that it can compete nationally and globally.

Based on data from OJK (2019), an increase in the performance of Islamic banking shows an average value of $34 \%$ and an optimistic market share of $5 \%$. Potential growth is more attractive for investors with a high growth because it is the only industry that showed a significant increase for the business year compared to similar companies. However, the problem of Islamic banking is related to the market share and total assets because conventional banks also experienced growth. Thus, Islamic banks need to create innovative products with financing 
features to achieve the target. One important aspect related to banking performance that can be done is to analyze the development of Islamic banking performance in Indonesia. Several indicators serve as a reference in analyzing banking performance, one of which is the liquidity condition of the bank. The liquidity ratio would be categorized as bad when Non-Performing Finance (NPF) is high (Arif \& Nauman Anees, 2012). Non-Performing Loans (NPL) of banks with small asset will increase rapidly when interest rates fluctuate, while increase in interest rates of banks with large assets will lead to a more significant reduction of the CAR (Ekananda, 2017).

Studies related to the level of banking efficiency and NPF become quite important when it comes to analyze the internal and external aspects that affect it. One form of analysis that can be done is to use Data Envelopment Analysis that calculates the utilization of inputs to produce multiple outputs (Havidz \& Setiawan, 2015) because efficiency and NPF bank is an important aspect in measuring the performance of the banking system. The increase in bad debts caused by external events, both unexpected and unpredictable external, such as the economic slowdown or interruption of companies that lead to bad luck hypothesis. This is because the loans can not be charged, the bank had to deal with the effort and incur additional costs. Then, poor management practices that cause bad credit because the bank's internal work is not in proportion, or in other words, poor management (Berger \& DeYoung, 1997).

Even though the condition of NPF is still in the safe level, but NPF of Islamic banking is still below $5 \%$. However, the current level is still quite high compared to conventional banking. The NPF fluctuations Islamic banking can be seen in Figure 1. Overall, the pattern of NPF was decline and had a positive meaning for Islamic banking. Even if on the monthly data, NPF Islamic Bank could be above 5\% such as in January 2016 until August 2016. However, NPF of Islamic banks had improved by the end of 2018, at around 3.26\%. Thus, Islamic banking is expected to continue to improve the performance so NPF can reach a lower point. The sectoral distribution of Islamic finance have an adverse effect on the NPL, which indicates that the growth of sectoral funding Islamic banks increase credit risk exposure over a conventional bank (Alandejani \& Asutay, 2017).

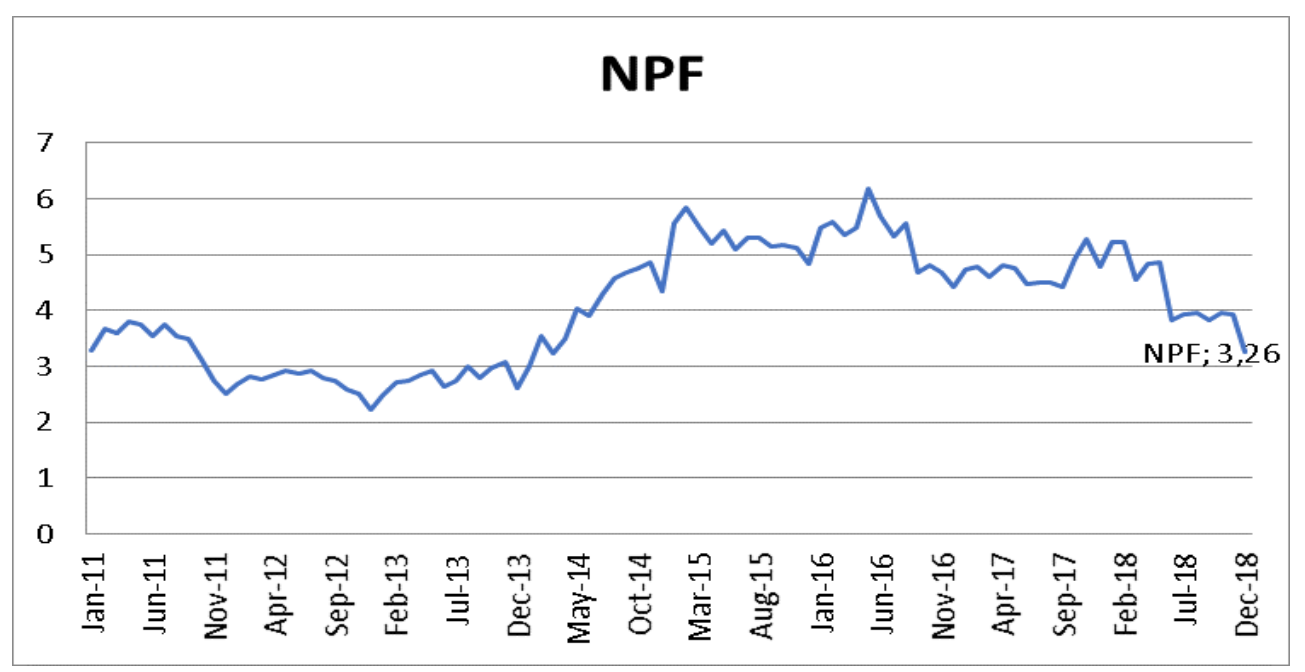

Source: Financial Services Authority, 2019 (processed data)

Figure 1. NPF chart on Islamic banking in Indonesia from January 2011 to December 2018

Some initial research related to the determinants of NPF has been carried out by Firmansyah (2012) presents the results of the influence of the GDP to financing problems have a negative correlation, meaning that an increase in GDP will make NPF ratio decreased. However, this study contrasts with research conducted by Nugrohowati \& Bimo (2019) about internal and 
external factors affecting Non-Performing Financing (NPF) of Sharia Rural Banks (BPRS) in Indonesia, specifically GDRP had a positive influence to NPF.

Other studies conducted by Misra \& Dhal (2010) describes the effect of LDR to NPL with a significant positive result. In other words, each increment of LDR will increase the potential for bad loans or NPL. This is contrary to the research conducted by (Diyanti \& Widyarti, 2012) in his study about the analysis of bank ratios, in his research shows the result of the influence of the LDR to NPL is significantly negative. That is, any increase in the LDR would lower the NPL ratio. According to Sudarsono (2017), Return on Assets (ROA) or profitability is a ratio used to measure the effectiveness of management to manage the amount of the profits from the banks. The greater the profits from the banks considered the banks' performance is getting better; the effect of the financing problems is also expected to be diminished.

The study conducted by Solihatun (2014) about analysis of NPF Islamic Banks in Indonesia in 2007-2012, suggests a significant positive outcome related to the effect of FDR on the NPL. In other words, any increase in FDR will be accompanied by an increase in NPL. However, the results of this study were different from the study of Havidz \& Setiawan (2015) about bank efficiency and Non-Performing Financing (NPF) in the Indonesian Islamic Bank, which found no significant results related to the effect of FDR on the NPL. That is, FDR has no connection to the NPL and there must be any other problems in the management of the company. Based on the research conducted by Solihatun (2014), it suggests that the effect of ROA on NPF has a significant negative relationship. Thus, any increase in ROA will be accompanied by a decrease in the NPF. It is then in opposition to the research conducted by Havidz \& Setiawan (2015) who found that ROA does not have a significant impact on NPF.

Subsequent research conducted by Chang (2006) points out the results of that CAR had a significant positive effect on the NPL. However, this opinion is disputed by Nugrohowati \& Bimo (2019) in his study on syariah rural banks in Indonesia, which states that the effect of CAR on the NPF is significantly negative, It is also different from the results of research conducted by Havidz \& Setiawan (2015) which states that the CAR does not have a significant effect on the NPL. Based on Havidz \& Setiawan (2015), there is no Islamic bank that consistently efficient for all the study periods by OTE, PTE, and SE. The overall results indicate that the efficiency of Islamic banks is significantly affected by the return on assets (ROA), the ratio of operational efficiency (OER), and the rate of inflation (INF), while the ratio of financing of the deposit (FDR), the capital adequacy ratio (CAR), size, and GDP growth rate did not significantly affect the efficiency of the bank. This study supports the hypothesis "Bad Management" for revealing that it may be due to the portfolio management of the Islamic Bank of Indonesia a bad period and the study sample.

From the above description, the results of research on factors affecting financing problems still diverse and very varied. Therefore, the authors are interested in researching back on Macro and Micro Determinants of the Non-Performing Finance: The Case of Indonesia Islamic Bank.

\section{Methods}

This study uses a quantitative approach with panel data analysis. This study uses secondary data as a basis for analysis with the composition of data derived from Reports Islamic bank annual report from the website of each bank from 2011 to 2018. The time range used in this study been citing the latest available data and the limited time available. The population in this study is an Islamic Bank in Indonesia, there are 14 registered Islamic Banks at OJK. There are 8 banks sampled in this study. Sample of this research, among others: Bank Mega Syariah, BCA Syariah, BNI Syariah BRI Syariah, Bank Syariah Mandiri, Maybank Syariah, and Bank Muamalat. The sampling method used by purposive sampling, which means that there are some provisions in the sample selection such as (1) the bank already registered OJK, (2) the bank has published financial 
statements in full in the year 2011 until 2018, (3) the bank is not a local bank, (4) the bank have positive profits and positive asset values.

This study uses panel data analysis because the composition of the data used is a combination of time series and cross-sections data. Then, in this study, Non-Performing Finance $(\mathrm{NPF})$ is an endogenous variable, whereas exogenous variables are described by several variables, which include the ratio of financing such as Financing Deposit Ratio (FDR), Return on Asset (ROA) and Capital Adequacy Ratio (CAR). The model in this study will be estimated using the Estimated Generalized Least Square (EGLS) that the data processing utilized by Eviews program version 9.0. This method is used to create error variance value becomes constant, where the value of the error variance dominates the observation will be relatively small, and the data becomes BLUE by way of a weighted or weighted cross-section (Gujarati \& Porter, 2009). The modeling study is stated as follows,

$N P F=\alpha_{i}+\beta_{1} G D P_{i t}+\beta_{2} C A R_{i t}+\beta_{3} C A R_{i t}+\beta_{4} F D R_{i t}+\varepsilon_{i t}$

Where NPF is Non-Performing Financing, GDP is Gross Domestic Product, CAR is Adequacy Capital Ratio, FDR is Financing to Deposit Ratio, ROA is Return On Asset and $\varepsilon_{i t}$ is Error term.

\section{Result and Discussion}

The discussion of this study will show the test results of macroeconomic factors and the performance of banks to financing problems as measured by the NPF on Islamic banking in Indonesia. The process of data analysis in this study begins with determining the best model in the data panel. This process is carried out through two stages, namely the chow test to choose between the common effect and fixed effect models and the Hausman test to choose either random or fixed effect model. The first stage is the testing of a model to determine the fixed effect model or common effect model to be used in this study using a chow test. The Chow test hypotheses as follows,

Ho: Common Effect

Ha: fixed Effect

Table 2. Likelihood Ratio Test Results

\begin{tabular}{lrrr}
\hline Effects Test & statistics & df & Prob. \\
\hline Cross-section F & 2.282676 & $(7.52)$ & 0.0418 \\
Cross-section Chi-square & 17.148873 & 7 & 0.0165 \\
\hline
\end{tabular}

The result of the Chow test in Table 2 is a test based on the likelihood ratio test. The result shows that the value of probability $F$ is 0.0418 and is less than alpha 0.05 , thus rejecting the null hypothesis, which means that the fixed effect model is the chosen model. However, a comparison of which model is better for the estimation then Hausman test is required.

The next step after the Chow test is the Hausman test. Determining the right model Hausman test is carried out with a probability of $5 \%$ with the hypothesis as follows,

Ho: Random Effect

Ha: fixed Effect

Table 3. Results of the Hausman Test

\begin{tabular}{lrrr}
\hline Test Summary & Chi-Sq. statistics & Chi-Sq. df & Prob. \\
\hline Cross-section random & 13.438978 & 4 & 0.0093 \\
\hline
\end{tabular}


The results of the Hausman test based on Table 3 shows a high probability is 0.0093 , which means the value is less than alpha values 0.005 . Therefore, the null hypothesis was rejected and the decision for the best model to use is a fixed effect.

This study uses panel data estimation model. Normality test results and specifications models are above, the estimation of the model should be used fixed effect estimation. In earlier tests, the model has been found to use the results of the estimate EGLS so consistent, and there is no bias. The estimation results EGLS panel data regression model are shown in Table 4. After getting the best model to do the analysis conducted in this study, including a partial test, test the whole model, and analyze the R-squared value.

Table 4. Results of Panel Data Regression

\begin{tabular}{crrrr}
\hline variable & \multicolumn{1}{c}{ coefficient } & \multicolumn{1}{l}{ Std. Error } & \multicolumn{1}{c}{ t-Statistic } & \multicolumn{1}{l}{ Prob. } \\
\hline C & 1.637226 & 1.369997 & 1.195059 & 0.2375 \\
GDP & $5.42 \mathrm{E}-08$ & $1.46 \mathrm{E}-07$ & 0.370605 & 0.7124 \\
CAR & 0.133277 & 0.037755 & 3.530083 & 0.0009 \\
FDR & $-7.59 \mathrm{E}-05$ & $2.25 \mathrm{E}-05$ & -3.372668 & 0.0014 \\
ROA & -1.319322 & 0.194932 & -6.768128 & 0.0000 \\
\hline
\end{tabular}

Testing regression coefficient was conducted to determine whether there is an influence throughout the exogenous variables on endogenous variables, either simultaneously or partially based on the level of significance was used. Based on Table 4 from the estimation results of the fixed effect model, partial testing can be done on the model with the alpha value $5 \%$. This partial test is carried out to test the effect of each independent variable on the dependent variable. In general, it can be concluded that the factors that influence the NPF value are CAR, FDR, and ROA, while the GDP variable does not affect the NPF value. Table 5 shows the results of the Ftest and the value of R-Squared.

Table 5. Estimation Results Hypothesis

\begin{tabular}{lll}
\hline R-squared & 0.738475 Mean dependent var & 9.206095 \\
Adjusted R-squared & $0.683152 \mathrm{SD}$ dependent var & 6.686722 \\
SE of regression & 3.155134 Sum squared resid & 517.6533 \\
F-statistic & 13.34849Durbin-Watson stat & 1.664443 \\
Prob (F-statistic) & 0.000000 & \\
\hline
\end{tabular}

Based on Table 5, the results of this regression showed the value of R-squared of 0.738475 , which means that the independent variables are able to explain the dependent variable in this study amounted to $73.85 \%$ and the rest are described using other factors beyond the study models. Furthermore, simultaneous testing of regression using F-test shows value of 13.349 with probability value 0.000 compared to alpha $5 \%$. Thus, the null hypothesis is rejected and it can be concluded that the overall effect of exogenous variables on endogenous variables together.

Based on our regression equations, the analysis process for partial testing used to test the effect of exogenous variables, namely GDP, CAR, FDR, and ROA on endogenous variables, namely NPF. Based on Table 4, the results of the analysis showed that the GDP variable has a regression coefficient 0.000000542 with a probability value of 0.7124 comparing with alpha $5 \%$, thus can not reject the null hypothesis and conclude that the GDP variable financing has no impact on NPF at the significance level of 5\%. This result suggests GDP as the individually variable effect is not significant in influencing positive NPF in 2011-2018. This is because GDP only affects the NPF in the long run and no impact in the short term according to the result of research conducted by Popita (2013). 
The results for the Capital Adequacy Ratio (CAR) variables in the partial regression analysis show that the variables have a regression coefficient 0.1333 with a probability value of 0.0009 comparing with alpha 5\%, thus reject the null hypothesis and conclude that the CAR variable has an impact on NPF at the significance level of 5\%. The variable CAR has an influence on a significance level of $5 \%$, and this shows the CAR individual variables have a significant effect in influencing NPF from 2011 to 2018. The regression coefficient indicates that the positive effect on NPF from 2011 to 2018 is CAR. The implication of the study shows that if the value of CAR increasing by $1 \%$ will be led to rising Islamic bank NPF at $0.133 \%$. This result is in line with the research conducted by Astrini, Suwendra, \& Suwarna, (2018); (Lidyah, 2016); Nugrohowati \& Bimo (2019); and Indah \& Arief (2016) which showed negative results. The results of this study showed positive results because the higher the CAR, the more the financial resources could lead to financial problems.

The next results of the variables Financing to Deposit Ratio (FDR) in the partial regression analysis show that the variables have a regression coefficient -0.0000759 with a probability value of 0.0014 comparing with alpha $5 \%$, thus reject the null hypothesis and conclude that the FDR variable has an impact on NPF at the significance level of $5 \%$. The regression coefficient shows that FDR negative effect on NPF from 2011 to 2018. This result implies if the magnitude of variable FDR increases of 1\% led to a decline NPF Islamic bank by $0.0000759 \%$. This result happens because the higher the liquidity of the bank will imply to reduce the risk of financing problems. An indication of the distribution of funds in Islamic banking with a good quality is to increase return and reduce NPF. These results are consistent and confirm the previous research by Diyanti \& Widyarti (2012) and Akbar (2016).

The last variable in the partial analysis is Return On Asset (ROA) in the partial regression analysis show that the variables have a regression coefficient -1.3193 with a probability value of 0.000 compared to alpha $5 \%$, thus reject the null hypothesis and conclude that the ROA variable has an impact on NPF at the significance level of $5 \%$. This result shows that ROA individually significant in influencing NPF from 2011 to 2018. The regression coefficient indicates that ROA negatively affect NPF from 2011 to 2018. This result implies if the magnitude of ROA increased $1 \%$ led to a decline of Islamic banking ROA at $1.3193 \%$. That is because a good performance of the company is a company that generates a better margin and gain which will reduce the financing problems. The results are consistent with previous research (Chaibi \& Ftiti, 2015; Dimitrios, Helen, \& Mike, 2016; Kjosevski \& Petkovski, 2017; Nugrohowati \& Bimo, 2019; and Solihatun, 2014).

\section{Conclusion}

In this study, the authors sought to estimate the impact of several variables that describe the performance of Islamic banking to the possibility of risk financing problems are interpreted through the NPF in Islamic banks in the last seven years, from 2011 to 2018.

Based on estimates of the relationship in the present study found a significant negative correlation between the FDR and ROA of Islamic banks against NPF from 2011 to 2018. It shows that the bank's profits would be obtained if the implementation of the FDR implemented with caution because when the bank was not careful, it can increase the chances of problematic credit risk. The CAR has a significant positive correlation to the NPF, which means that the bank can cover the credit risk that occurs in the presence of a reserve fund capital ratio and the riskweighted assets. However, monetary factors such as GDP did not have a significant impact on Islamic banks NPF this case because GDP still can not be measured in the short term. But simultaneously, the exogenous variables affect the endogenous variables, which means that it affects NPF during 2011-2018. That is, in the mitigation of risk to an increase in its main NPF in terms of GDP, CAR, FDR, and ROA should be developed further because these variables have a significant relationship to the NPF. Although the GDP variable should be reassessed. 
Still, there is a limitation in this study which can be developed further for the next research. Variable supporters of each Islamic bank's financial indicators can be used for further research, as an indicator of liquidity, solvency, liabilities, and earnings. Hopefully it can obtain more meaningful results and determine what variables that most influence the NPF in order to reduce the risk of Islamic bank financing in the future.

\section{References}

Akbar, D. A. (2016). Inflasi, Gross Domestic Product (GDP), Capital Adequacy Ratio (CAR), dan Finance to Deposit Ratio (FDR) Terhadap Non Performing Financing (NPF) pada Bank Umum Syariah di Indonesia. I-Economic, 2(2), 19-37. Retrieved from http://jurnal.radenfatah.ac.id/index.php/ieconomics/article/view/1021/855

Alandejani, M., \& Asutay, M. (2017). Nonperforming loans in the GCC banking sectors: Does the Islamic finance matter? Research in International Business and Finance, 42(June 2016), 832854. https://doi.org/10.1016/j.ribaf.2017.07.020

Arif, A., \& Nauman Anees, A. (2012). Liquidity risk and performance of banking system. Journal of Financial Regulation and Compliance, 20(2), 182-195. https://doi.org/10.1108/13581981211218342

Astrini, K. S., Suwendra, I. W., \& Suwarna, I. K. (2018). Pengaruh CAR, LDR, dan Bank Size terhadap NPL pada Lembaga Perbankan yang Terdaftar di Bursa Efek Indonesia. Bisma: Jurnal Manajemen, 4(1), 34-41. Retrieved from https://ejournal.undiksha.ac.id/index.php/BISMA-JM/article/view/21977/13607

Berger, A. N., \& DeYoung, R. (1997). Problem Loans and Cost Efficiency in Commercial Banks. Finance and Economics Discussion Series, 1997(08), 1-29. https://doi.org/10.17016/feds.1997.08

Chaibi, H., \& Ftiti, Z. (2015). Credit risk determinants: Evidence from a cross-country study. Research in International Business and Finance, 33, 1-16. https://doi.org/10.1016/j.ribaf.2014.06.001

Chang, Y. T. (2006). Role of Non-Performing Loans (NPLs) and Capital Adequacy in Banking Structure and Competition (No. 06-15). Norwich.

Dimitrios, A., Helen, L., \& Mike, T. (2016). Determinants of non-performing loans: Evidence from Euro-area countries. Finance Research Letters, 18, 116-119. https://doi.org/10.1016/j.frl.2016.04.008

Diyanti, A., \& Widyarti, E. T. (2012). Analisis Pengaruh Faktor Internal dan Eksternal Terhadap Terjadinya Non-Performing Loan (Studi Kasus pada Bank Umum Konvensional yang Menyediakan Layanan Kredit Pemilikan Rumah Periode 2008-2011). Diponegoro Journal of Management, 1(2), 290-299.

Ekananda, M. (2017). Macroeconomic Condition and Banking Industry Performance in Indonesia. Buletin Ekonomi Moneter Dan Perbankan, 20(1), 71-98. https://doi.org/https://doi.org/10.21098/bemp.v20i1.725

Ghosh, M., Ghoshray, A., \& Malki, I. (2013). Regional divergence and club convergence in India. Economic Modelling, 30(1). https:// doi.org/10.1016/j.econmod.2012.10.008

Gujarati, D., \& Porter, D. C. (2009). Basic Econometrics (5th Editio). New York: McGraw-Hill Irwin.

Havidz, S. A. H., \& Setiawan, C. (2015). Bank Efficiency and Non-Performing Financing (NPF) 
in The Indonesian Islamic Banks. Asian Journal of Economic Modelling, 3(3), 61-79. https://doi.org/10.18488/journal.8/2015.3.3/8.3.61.79

Indah, D., \& Arief, P. (2016). Pengaruh Non Performing Loan (NPL) dan Capital Adequacy Ratio (CAR) Terhadap Profitabilitas. Management Analysis Journal, 5(2), 110-115.

Kjosevski, J., \& Petkovski, M. (2017). Non-performing loans in Baltic States: Determinants and macroeconomic effects. Baltic Journal of Economics, 17(1), 25-44. https://doi.org/10.1080/1406099X.2016.1246234

Lidyah, R. (2016). Dampak Inflasi , BI RATE, Capital Adequacy Ratio (CAR), Biaya Operasional Pendapatan Operasional (BOPO) Terhadap Non Performing Financing (NPF) pada Bank Umum Syariah di Indonesia. I-Finance, 2(1), 1-19. Retrieved from http://jurnal.radenfatah.ac.id/index.php/I-Finance/article/view/1006/840

Misra, B., \& Dhal, S. (2010). Pro-cyclical management of non-performing loan by the Indian Public Sector Bank. BIS Asian Research Paper. Retrieved from http://www.bis.org/repofficepubl/arpresearch201003.08.pdf

Nugrohowati, R. N. I., \& Bimo, S. (2019). Analisis pengaruh faktor internal bank dan eksternal terhadap Non-Performing Financing (NPF) pada Bank Perkreditan Rakyat Syariah di Indonesia. Jumal Ekononomi \& Kenangan Islam, 5(1), 42-49. https://doi.org/10.20885/JEKI.vol5.iss1.art6

OJK. (2019). Statistik Perbankan Syariah. Retrieved from https://www.ojk.go.id/id/kanal/syariah/data-dan-statistik/statistik-perbankan-

syariah/Documents/Pages/Statistik-Perbankan-Syariah---Januari-2019/SPS Januari 2019.pdf

Popita, M. S. A. (2013). Analisis Penyebab Terjadinya Non Performing Financing Pada Bank Umum Syariah Di Indonesia. Accounting Analysis Journal, 2(4), 404-412. https://doi.org/https://doi.org/10.15294/aaj.v2i4.2884

Solihatun. (2014). Analisis Non Performing Financing (NPF) Bank Umum Syariah di Indonesia Tahun 2007 - 2012. Jurnal Ekonomi Pembangunan, 12(1), 57-68. https://doi.org/https://doi.org/10.22219/jep.v12i1.3655

Sudarsono, H. (2009). Dampak Krisis Keuangan Global terhadap Perbankan di Indonesia: Perbandingan antara Bank Konvensional dan Bank Syariah. La_Riba Journal Ekonomi Islam, III(1), 12-23. https:// doi.org/10.20885/lariba.vol3.iss1.art2

Sudarsono, H. (2017). Analisis Pengaruh Kinerja Keuangan terhadap Profitabilitas Bank Syariah di Indonesia. Economica: Jurnal Ekonomi Islam, 8(2), 175-203. http://dx.doi.org/10.21580/economica.2017.8.2.1702 